\title{
Bilateral elastofibroma dorsi: a case report of an uncommon and under-diagnosed tumor
}

\author{
Stefanie Braun, Matthias Richter, Tom Ernst, Andreas Flade, Dirk Uhlmann \\ Klinikum Doebeln, Germany
}

Kardiochirurgia i Torakochirurgia Polska 2015; 12 (4): 355-358

\begin{abstract}
Elastofibroma dorsi is a rare benign tumor of the back, located between the latissimus dorsi and the rhomboid muscle. In most cases it is unilateral, but in up to $10 \%$ it occurs on both sides. The etiology is still in discussion. Here we report a case of a 51-year-old man with bilateral elastofibroma dorsi. The therapy of choice was surgical resection. No long-term complications were reported in a 6-month follow-up.

Key words: elastofibroma, soft tissue, tumor, thoracic wall.
\end{abstract}

\section{Introduction}

Elastofibroma dorsi is a rare, benign non-encapsulated tumor of the soft tissue. In most cases it occurs on the dorsal thoracic wall under the inferior angle of the scapula. In $10 \%$ of cases it appears bilaterally [1]. However, some cases are described with the location at the mediastinum, the stomach, the intraspinal space and others [2-4]. Females are more affected than males $(3.9: 1)$, and the mean age is about 62 years [5]

In this paper we report a case of a 51-year-old man with bilateral elastofibroma dorsi.

\section{Case report}

A 51-year-old man came to the hospital with pain in his left shoulder while sitting and when elevating his arm, present for 2 months. While moving there was also a snapping of the left scapula. He also described slow growing tumors among the scapula on the right side for 3 years and for 2 years on the left. Former diagnostics including magnetic resonance imaging (MRI) did not show any pathological findings. His profession is a paver. There was no family history of soft tissue tumors. The physical examination showed two bilateral tumors on the inferior angle of the scapula,

\section{Streszczenie}

Włókniak sprężysty grzbietu, zwany też włókniakiem z włókien elastycznych (elastofibroma dorsi), jest rzadkim łagodnym guzem występującym w obszarze pleców pomiędzy mięśniem najszerszym grzbietu a mięśniami równoległobocznymi. Guz rozwija się zazwyczaj jednostronnie, ale w 10\% przypadków występuje po obu stronach. Jego etiologia wciąż jest przedmiotem dyskusji. W pracy przedstawiono przypadek 51-letniego pacjenta z obustronnym włókniakiem sprężystym grzbietu. Leczeniem z wyboru była resekcja chirurgiczna. W czasie jednorocznej obserwacji nie odnotowano żadnych odległych powikłań.

Słowa kluczowe: włókniak sprężysty grzbietu, tkanka miękka, guz, ściana klatki piersiowej.

only visible when the arms were adducted and elevated to the front. Magnetic resonance imaging was performed to evaluate the tissue of origin and measure the size. There were two $8 \times 6 \times 2.5 \mathrm{~cm}$ tumors on the dorsolateral thoracic wall near the scapula, located between the dorsolateral middle ribs and the serratus anterior muscle. Figure 1 shows the MRI scan of the patient. Because no criteria of malignancy were met, no preoperative puncture was done.

As recommended in the literature, a surgical resection was performed in general anesthesia. The patient was placed in a prone position and the arms were elevated to let the inferior angle of the scapula slide laterally. A semilunar incision of the skin was made around the angle of the scapula, first on the left side (Fig. 2). Then the latissimus muscle was cut and the tumor was removed with some surrounding fat tissue. The same procedure was performed on the right side.

The pathological and histopathological examination of the tumors showed two mesenchymal tumors, $7 \times 5.5 \times 3.4 \mathrm{~cm}$ on the left and $7.6 \times 7.4 \times 3.0 \mathrm{~cm}$ on the right side, with fibrosis and an increased amount of elastic fibers. Both tumors were diagnosed as elastofibroma dorsi (Figs. 3 and 4).

Postoperative vacuum drainage of the wounds was performed for 2 days. However, a hematoma and later

Address for correspondence: Prof. Dirk Uhlmann, Klinikum Doebeln, Sörmitzer Str. 10, 04720 Döbeln, Germany, phone: 00493431722100 , e-mail: dirk.uhlmann@klinikum-doebeln.de 

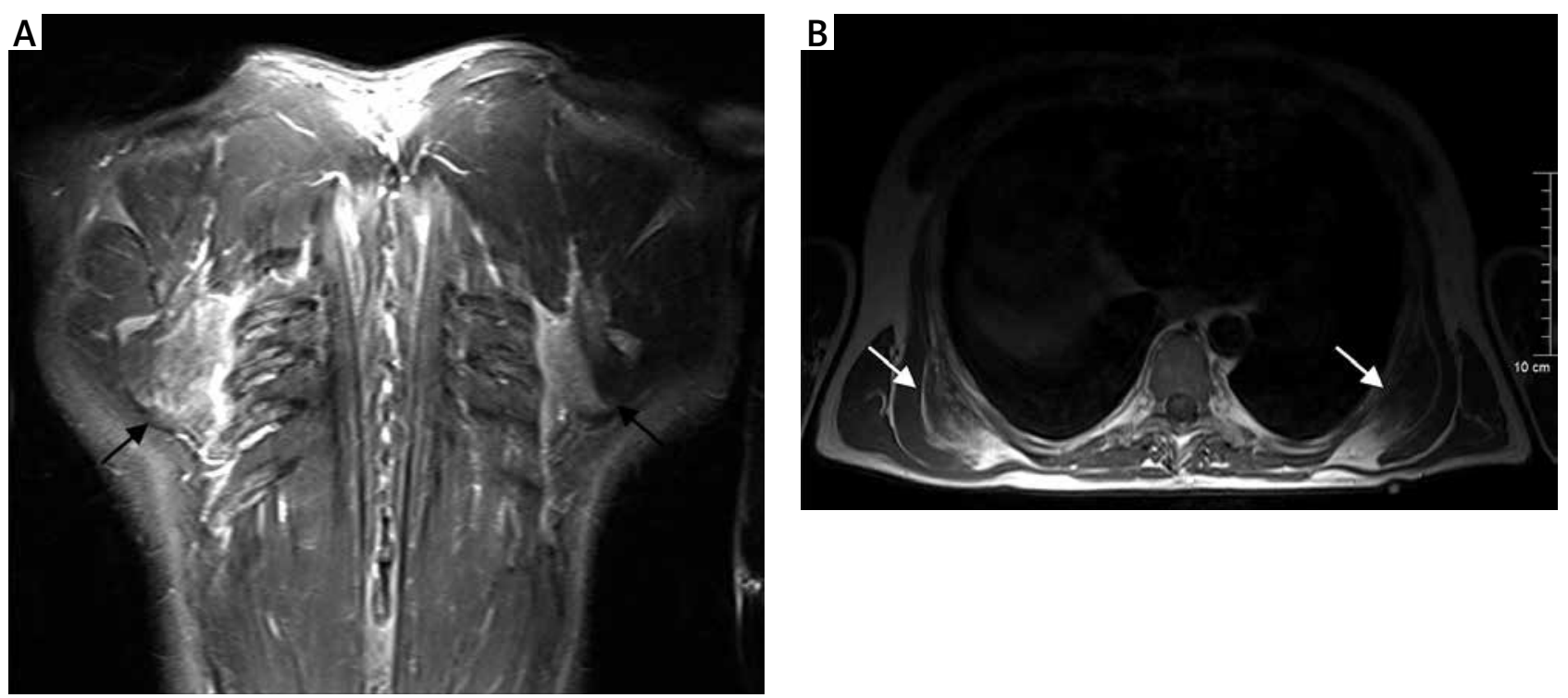

Fig. 1. Magnetic resonance images of bilateral elastofibroma dorsi: the tumor is located between the dorsolateral-middle ribs and the serratus anterior muscle on both sides (coronal T2 weighted (A) and axial (B) T1 weighted images). The arrows indicate the margins of the tumors
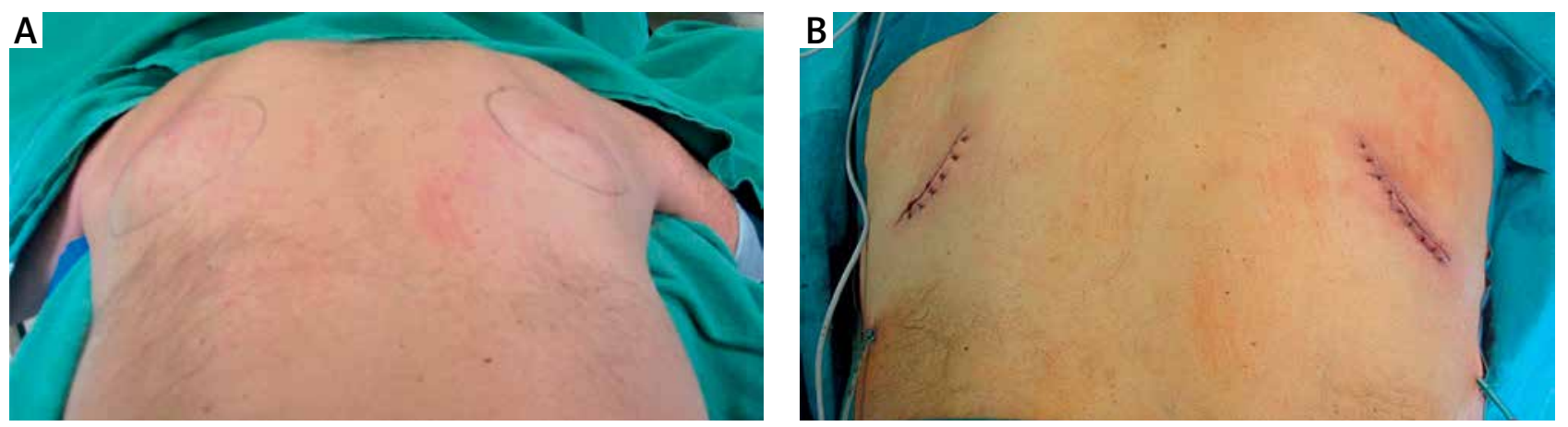

Fig. 2. Aspect of the patient before (A) and after (B) surgical removal of the tumor

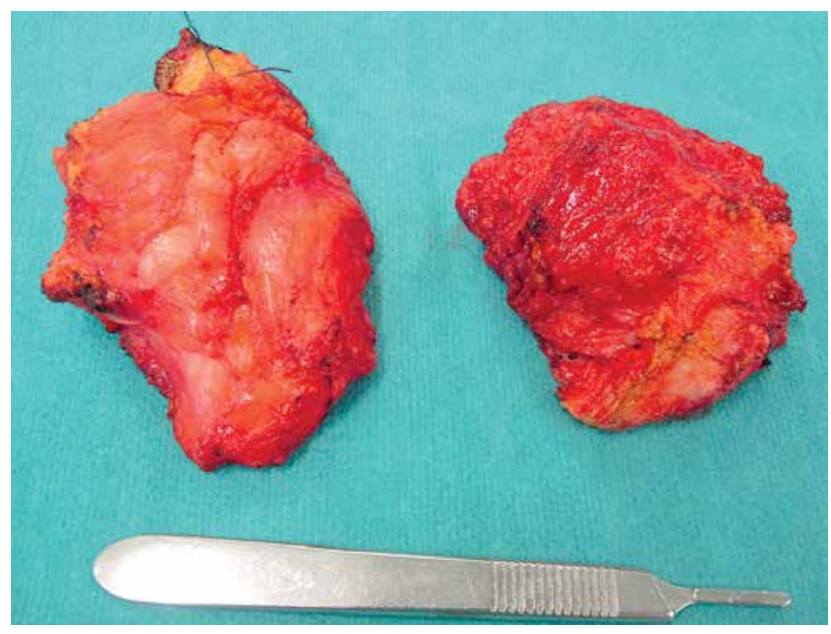

Fig. 3. Macroscopic aspect of the resected elastofibroma (left side is marked with a strand): fatty and connective tissue with no capsule with grey/white fibrosis on the cut surface

a seroma on the right side occurred. The hematoma was evacuated and later the seroma has to be drained. After drainage for 3 days there was no more wound secretion.
No long-term complications were reported in a 6-month follow-up.

\section{Discussion}

Elastofibroma dorsi is a benign tumor of the dorsal thoracic wall, first described in 1961 by Järvi and Saxén [6]. The tumor is not as rare as often reported. In autopsy studies elastofibroma-like tissue at the back was found in $24.4 \%$ of female and $11.2 \%$ of male patients older than 55 years [7]. In another study using a CT scan, done because of other thoracic pathologies, the prevalence of elastofibroma dorsi was $2 \%$ in a population of elderly patients [8]. Similar findings were obtained by Blumenrantz et al. in a (18)FDGPET/CT study [9].

Nevertheless, it may be reported as a rare tumor because it does not often cause symptoms. The patients complain about shoulder pain during arm movement, scapula snapping or a clicking sensation [10, 11]. In a study of 71 cases just $46.5 \%$ of the patients had such specific symptoms [12].

The genesis of elastofibroma dorsi is still unclear. A theory describes the cause of micro traumata as repetitive movement of the scapula-thoracic joint, for example by 


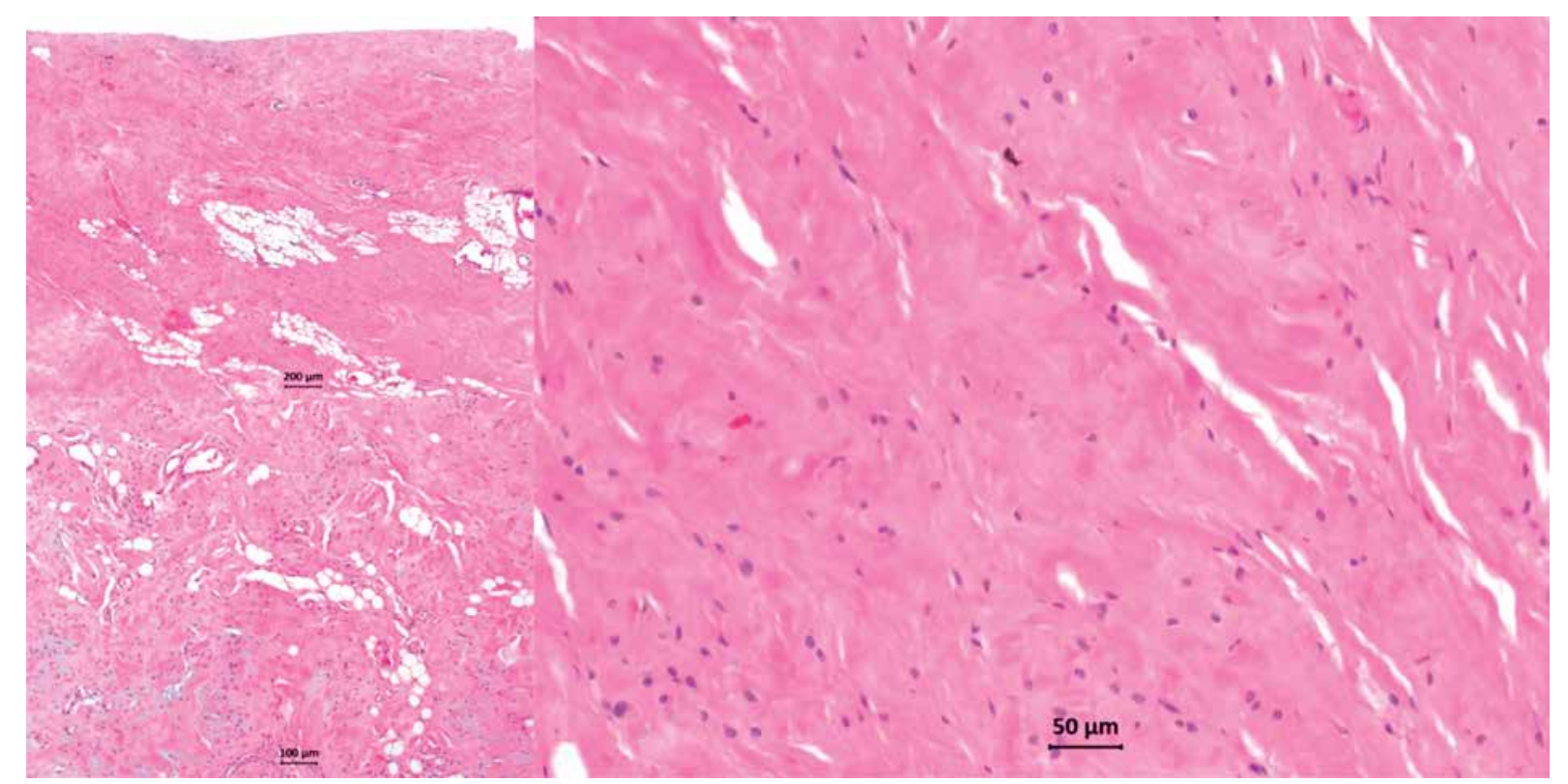

Fig. 4. Histology of elastofibroma dorsi in different magnifications (hematoxylin-eosin staining): fatty tissue with a diffuse defined mesenchymal tumor. It shows fibrosis and an increased amount of elastic fibers

manual workers or hobbies using the hand/shoulder. This may lead to reactive growth of fibroelastic fibers. There are some studies which support this theory. For example, in a study of 30 patients with elastofibroma dorsi $63 \%$ did hand knitting [13]. Also our patient was a manual worker. But Daigler et al. found that there is no correlation between the dominant hand and the side of occurrence of elastofibroma dorsi [14]. Also this theory does not explain other locations of elastofibroma dorsi, for example at the stomach or the intraspinal space $[3,4]$. There is some evidence that hereditary factors play an important role in the etiology of elastofibroma dorsi [15].

Elastofibroma dorsi in most cases appears unilaterally, preferring the right side [15]. But it may also grow bilaterally, depending on the study with a frequency from $10 \%$ to $51 \%[1,5]$. Often just one side exhibits symptoms and the tumor on the opposite side is overlooked. It is also reported that even when one side is removed, a recurrence can occur on the contralateral side [16]. Because of that a carefully physical examination and imaging, e.g. with MRI, is necessary.

Surgical removal of the tumors is the treatment of choice. A common postoperative complication is the formation of seroma or hematoma [13, 14], as also seen in our patient. Recurrence after surgery is reported in just a few cases [15]. No long-term morbidity or mortality is reported [17].

Although the definitive diagnosis can be made only with complete excision of the tumor and malignancy cannot be ruled out without exeresis, we recommend resection in patients with symptomatic lesions or when the clinical-radiological findings are insufficient to confirm the diagnosis of elastofibroma. The post-operative period is short, with limited morbidity and mortality, although there is a possibility of hematoma of the surgical bed, se- roma of the wound and recurrence if the margins are not wide enough, which in some cases is difficult to determine [18].

\section{Disclosure}

Authors report no conflict of interest.

\section{References}

1. Briccoli A, Casadei R, Di RM, Favale L, Bacchini P, Bertoni F. Elastofibroma dorsi. Surg Today 2000; 30: 147-152.

2. De NM, Goteri G, Campanati G, Prat J. Elastofibrolipoma of the mediastinum. A previously undescribed benign tumor containing abnormal elastic fibers. Am J Surg Pathol 1995; 19: 364-367.

3. Enjoji M, Sumiyoshi K, Sueyoshi K. Elastofibromatous lesion of the stomach in a patient with elastofibroma dorsi. Am J Surg Pathol 1985; 9: 233-237.

4. Prete PE, Henbest M, Michalski JP, Porter RW. Intraspinal elastofibroma. A case report. Spine 1983; 8: 800-802.

5. Go PH, Meadows MC, Deleon EM, Chamberlain RS. Elastofibroma dorsi: a soft tissue masquerade. Int J Shoulder Surg 2010; 4: 97-101.

6. Jarvi O, Saxen E. Elastofibroma dorse. Acta Pathol Microbiol Scand Suppl 1961; 51 (Suppl 144): 83-84.

7. Jarvi $\mathrm{OH}$, Lansimies $\mathrm{PH}$. Subclinical elastofibromas in the scapular region in an autopsy series. Acta Pathol Microbiol Scand A 1975; 83: 87-108.

8. Brandser EA, Goree JC, El-Khoury GY. Elastofibroma dorsi: prevalence in an elderly patient population as revealed by CT. Am J Roentgenol 1998; 171: 977-980.

9. Blumenkrantz Y, Bruno GL, Gonzalez CJ, Namias M, Osorio AR, Parma P. Characterization of elastofibroma dorsi with (18)FDG PET/CT: a retrospective study. Rev Esp Med Nucl 2011; 30: 342-345.

10. Kara M, Dikmen E, Kara SA, Atasoy P. Bilateral elastofibroma dorsi: proper positioning for an accurate diagnosis. Eur J Cardiothorac Surg 2002; 22: 839-841.

11. Majo J, Gracia I, Doncel A, Valera M, Nunez A, Guix M. Elastofibroma dorsi as a cause of shoulder pain or snapping scapula. Clin Orthop Relat Res 2001; 388: 200-204.

12. Lococo F, Cesario A, Mattei F, Petrone G, Vita LM, Petracca-Ciavarella L, Margaritora S, Granone P. Elastofibroma dorsi: clinicopathological analysis of 71 cases. Thorac Cardiovasc Surg 2013; 61: 215-222.

13. Findikcioglu A, Kilic D, Karadayi S, Canpolat T, Reyhan M, Hatipoglu A. A thoracic surgeon's perspective on the elastofibroma dorsi: a benign tumor of the deep infrascapular region. Thoracic Cancer 2013; 4: 35-40. 
14. Daigeler A, Vogt PM, Busch K, Pennekamp W, Weyhe D, Lehnhardt M, Steinstraesser L, Steinau HU, Kuhnen C. Elastofibroma dorsi - differential diagnosis in chest wall tumours. World J Surg Oncol 2007; 5: 15.

15. Nagamine N, Nohara Y, Ito E. Elastofibroma in Okinawa. A clinicopathologic study of 170 cases. Cancer 1982; 50: 1794-1805.

16. Giannotti S, Bottai V, Dell'osso G, Bugelli G, Cazzella N, Guido G. Elastofibroma dorsi: case series of a rare benign tumour of the back. Eur J Orthop Surg Traumatol 2013; 23: 643-645.
17. El Hammoumi M, Qtaibi A, Arsalane A, El Oueriachi F, Kabiri el H. Elastofibroma dorsi: clinicopathological analysis of 76 cases. Korean J Thorac Cardiovasc Surg 2014; 47: 111-116.

18. Ramos R, Ureńa A, Macía I, Rivas F, Ríus X, Armengol J. Elastofibroma dorsi: an uncommon and under-diagnosed tumour. Arch Bronconeumol 2011; 47: 262-263. 